\title{
オルダム継手の運動解析と静力学*
}

\author{
小松原 英 範*1, 三留 謙 一 $^{* 1}$

\section{Motion Analysis and Statics of Oldham Coupling}

Hidenori KOMATSUBARA*2 and Ken-ichi MITOME

*2 Department of Mechanical System Engineering, Yamagata University, 4-3-16 Jonan, Yonezawa shi, Yamagata, 992-8510 Japan

\begin{abstract}
The Oldham coupling transmits a rotary motion with constant velocity between two parallel shafts. This Oldham coupling consists of the three elements; the input shaft, the intermediate element, and the output shaft. The motion of the intermediate element is similar to that of the "hulahoop". As a result, the input torque cyclically changes under the constant output torque. First the motion of the intermediate element of the Oldham coupling is analyzed. An instantaneous center of rotation of the intermediate element is found. The fixed centrode is obtained as the locus of this center in the fixed coordinate system. The moving centrode is also obtained as the locus of this center in the moving coordinate system attached on the intermediate element. Input torque is obtained by analysis and statics. Secondly, the Oldham coupling is designed and made. Input torque is measured compared with theoretical one. Thus the motion of Oldham coupling is verified theoretically and experimentally.
\end{abstract}

Key Words : Oldham Coupling, Motion Analysis, Statics, Fixed Centrode, Moving Centrode, Intermediate Element

\section{1. 緒論}

オルダム継手は平行な 2 軸間に等速回転運動を伝え ることができる。このためオルダム継手は主に軸継手 として利用されている。その他の利用法としてはだ円 チャックへの可能性が示されている(1)(2). しかしまだ 実用化はされていない.

このオルダム継手は, 入力節, 中間節, 出力節の三 つから構成される.そしてその中間節はフラフープの ような運動をする，中間節のこの運動により，入力軸 にトルク変動が生じる.

さて著者らは, オルダム継手に基づいた，だ円切削 装置の実用化を目指している。だ円切削装置の開発に はこのトルク変動の解明が不可欠である.

そこで, 本研究ではだ円切削装置開発の基礎研究と してオルダム継手の中間節の運動特性および入出力軸 のトルク特性を明らかにする，本報では，まずオルダ ム継手の中間節の運動解析を行う。このときオルダム 継手の中間節の運動を, 中間節の瞬間中心 $\mathrm{P}$ の移動軌 跡 $\Gamma_{m}$ が，その固定軌跡 $\Gamma_{f}$ の周りを転がり運動する

* 原稿受付 2004 年 6 月 10 日

*1 正員, 山形大学工学部 (-492-8510 米沢市城南 4-3-16).

E-mail : hkomatsu@yz.yamagata-u.ac.jp
ことにより表現する．次に，負荷トルクを一定とした 場合のオルダム継手の入力トルクを理論的に求める. そして実際にオルダム継手を製作し，入力トルクを測 定し，その理論值と比較する。こうしてオルダム継手 の運動を検証する。

\section{2. オルダム継手の中間節の運動解析}

図 1 にオルダム継手を示す。オルダム継手は固定両 スライダ機構, 回り両スライダ機構から連鎖の交替に よって得られるので, 以下では, 回り両スライダ機構 に置換えて解析を行う。

\section{$2 \cdot 1$ 中間節にある 2 本の直線溝が直交する場合}

二つの直交する直線溝を持つ回り両スライダ機構を 図 2 に示す.ここでこの機構の二つの回転角を考え る. 入力軸回転角を $\phi$, 出力軸回転角を $\psi$ とした場 合，これらの関係は図 2 より次式で表される。なお $\phi$ と $\psi$ は反時計回りを正とする.

$$
\phi=\phi+\pi / 2 \text {. }
$$

時間 $t$ で両辺を微分して,

$$
\mathrm{d} \psi / \mathrm{d} t=\mathrm{d} \phi / \mathrm{d} t
$$

ゆえに,オルダム継手は, オフセットされている二軸 間に等速回転運動を伝える。

図 3 に中間節にある 2 本の直線溝が直交している回 
り雨スライダ機構を示す. 図 3 において, 座標系 $\mathrm{B}_{0^{-}}$ $x y$ は静止節 D に固定した静止座標系であり，座標系 O-XY は中間節 C に固定した動座標系である。いま 入力節 $\mathrm{A}$ が，反時計回りに回転して中間節 C に運動 を伝え,さらに中間節 Cが出力節 B に連動を伝える とする。このとき, 中間節 CO瞬間中心は点 $\mathrm{P}$ とな 子.
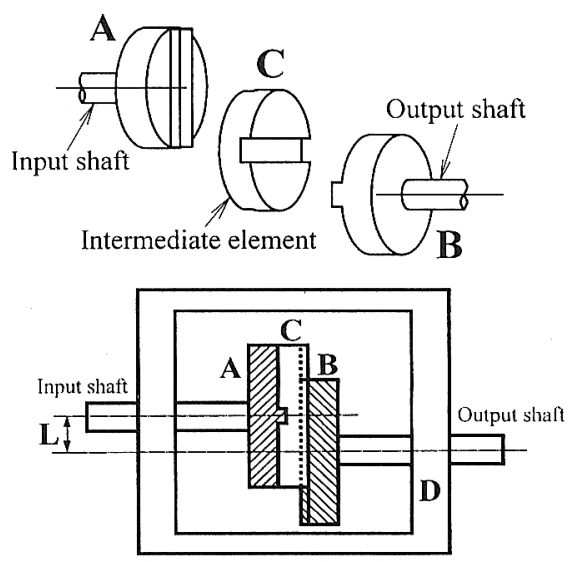

Fig. 1 Oldham coupling

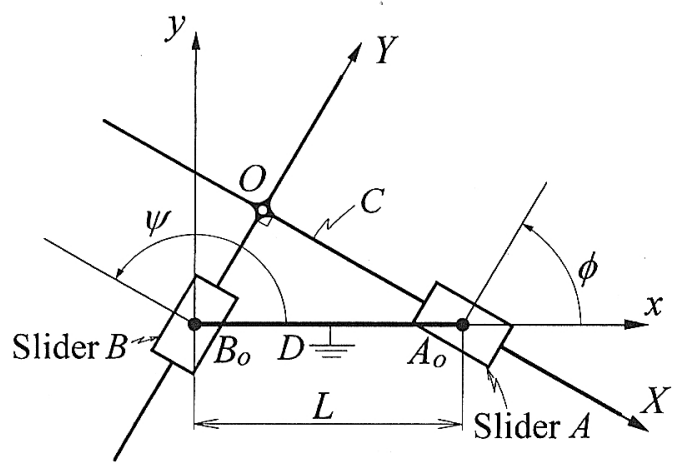

Fig. 2 Turning block double slider crank mechanism
ここで，静止座標系でとらえた瞬間中心 $\mathrm{P}$ の軌跡を 固定軌跡と呼び， $\Gamma_{f}$ とる。また，動座標系でとらえ た瞬間中心 $\mathrm{P}$ の軌跡を移動軌跡と呼び， $\Gamma_{m}$ とする。

瞬間中心の移動軌跡 $\Gamma_{m}$ は, 点 $\mathrm{P}$ 動座標系 $\mathrm{O}^{-}$ $X Y$ でとらえたものであり, $\overline{\mathrm{A}_{0} \mathrm{~B}_{0}}=L$ として次式に よって求められる。

$$
\mathrm{P}(X, Y) ; X=L \sin \phi, Y=-L \cos \phi
$$$$
X^{2}+Y^{2}=L^{2}
$$

また，瞬間中心 $\mathrm{C} の$ 固定軌跡 $\Gamma_{f}$ は，点 $\mathrm{P}$ を静止座 標系 $\mathrm{B}_{0}-x y$ でとらえたものであり，次式によって表 さ㧈る。

$$
\begin{aligned}
& \mathrm{P}(x, y) ; x=X \sin \phi=L \sin ^{2} \phi \\
& y=-X \cos \phi=-L \sin \phi \cos \phi \\
&(x-L / 2)^{2}+y^{2}=(L / 2)^{2} \ldots \ldots \ldots \ldots \ldots \ldots \ldots \ldots . .
\end{aligned}
$$

このように，中間節 C にある 2 本の直線溝が直交し ている場合，中間節の移動軌跡 $\Gamma_{m}$ は点 $\mathrm{O}$ 中心とす る半径 $L$ のとなり, 固定軌跡 $\Gamma_{f}$ 注, 静止節の中点 を中心とする半径 $L / 20$ 円となる。 そして二つの円

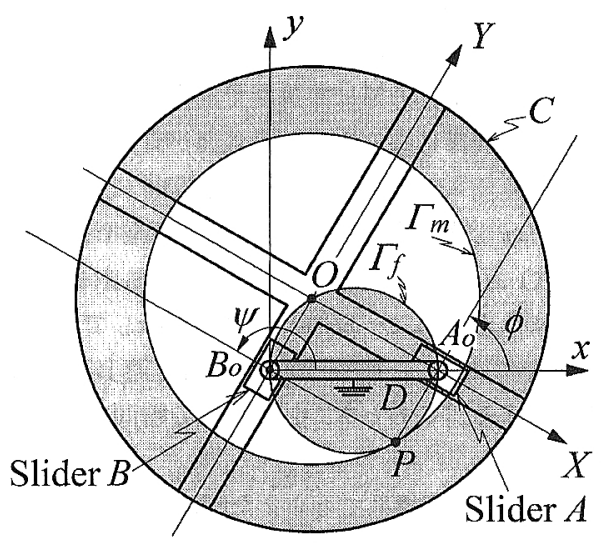

Fig. 3 Moving centrode and fixed centrode of Oldham coupling

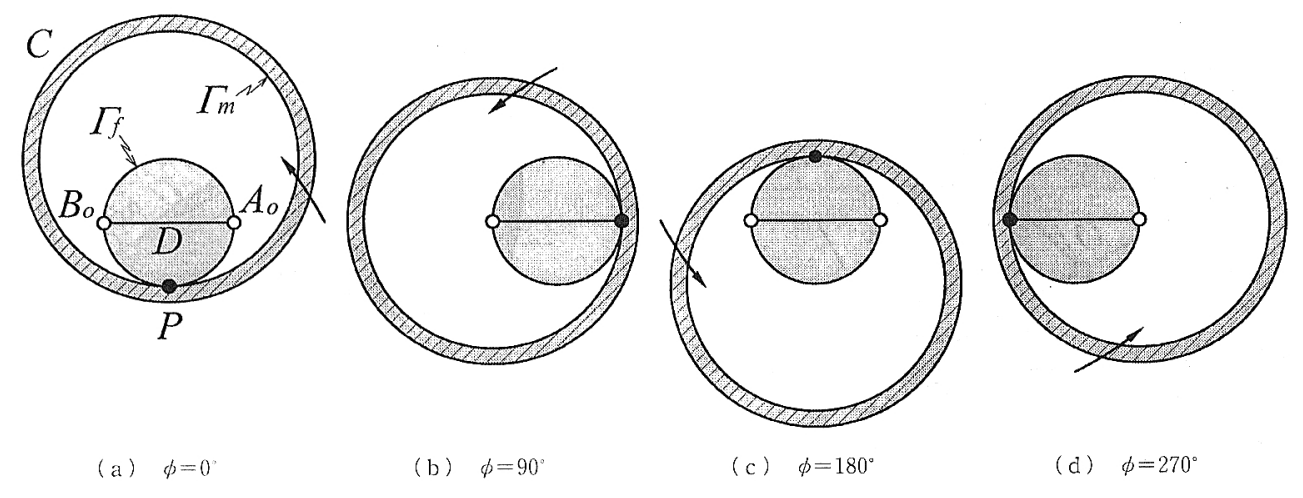

Fig. 4 Motion of moving centrode to fixed centrode during single rotation of input shaft of Oldham coupling 
は点 $\mathrm{P} て ゙$ 常に接する。軌跡 $\Gamma_{m}$ の内側は, 軌跡 $\Gamma_{f}$ の 外側を転がりながら運動する。

中間節が 1 回転する間に, 軌跡 $\Gamma_{f}$ と軌跡 $\Gamma_{m}$ の接 触点は，軌跡 $\Gamma_{m}$ の円周を 2 周する，中間節の中心は， 常に軌跡 $\Gamma_{f}$ の上にあり，しかも接触点の真向かいに ある。すなわち，入力節が $\omega$ の角速度で回転すると き, 中間節の重心は, $2 \omega$ の角速度で円 $\Gamma_{f}$ の円周上を 回転する.

よってオルダム継手の中間節 C は, 図 4 に示すよう に，中閒節 Cに固定された軌跡 $\Gamma_{m}$ の内側が，固定節 $\mathrm{D}$ に固定された軌跡 $\Gamma_{f}$ の外側を転がり，いわゆるフ ラフープのような運動をしている。

\section{$2 \cdot 2$ 中間節にある 2 本の直線溝が直交しない場合}

図 5 に中間節にある 2 本の直線淦が直交しない場合 の回り両スライダ機構を示す。図 5 で, 角 $\beta$ は 2 本の 浑のなす角である. 入力軸回転角を $\phi$, 出力軸回転角

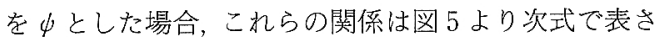
れる。

$$
\begin{aligned}
& \psi=\phi+\beta=\phi+\gamma+\pi / 2 \\
& \mathrm{~d} \psi / \mathrm{d} t=\mathrm{d} \phi / \mathrm{d} t
\end{aligned}
$$

よって, 中間節にある 2 本の直線溝が直交しない場 合でも入力節と出力節は等速度で回転する.

図 6 に中間節にある 2 本の直線瑇が直交していない 場合の回り両スライダ機構を示す．図 6 に招いて, 座 標系 $\mathrm{B}_{0}-x y$ は静止節 D に固定した静止座標系であり, 座標系 $\mathrm{O}-X Y$ は中間節 C k固定した動座標系であ る.いま入力節 $\mathrm{A}$ が, 反時計回りに回転して中間節 $\mathrm{C}$ に運動を伝え, さらに中間節 Cが出力節 $\mathrm{B}$ に運動を 伝えるとする。このとき，中間節 C の瞬間中心は点 $\mathrm{P}$ となる。

ここで, 静止座標系でとらえた瞬間中心 P O固定軌 跡 $\Gamma_{f}$ と動座標系でとらえた瞬間中心 $\mathrm{P} の$ 移動軌跡 $\Gamma_{m}$ を求める。瞬間中心の移動軌跡 $\Gamma_{m}$ は, 点 $\mathrm{P}$ を動 座標系 O- $X Y$ でとらえたものであり, $\overline{\mathrm{A}_{0} \mathrm{~B}_{0}}=L$ とし

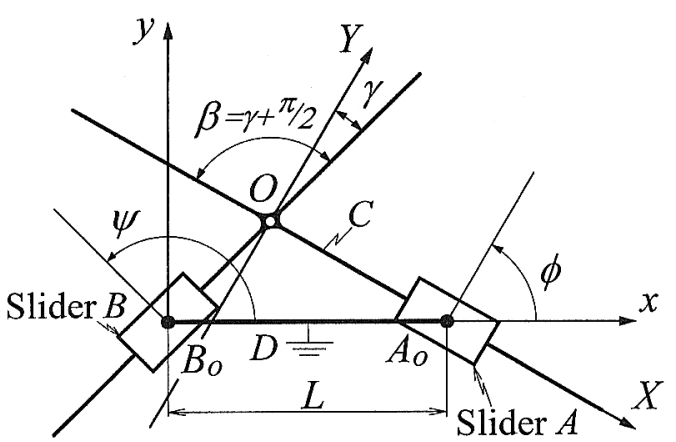

Fig. 5 Turning block double slider crank mechanism
て次式によって求められる。

$$
\left.\begin{array}{l}
\mathrm{P}(X, Y) ; X=L^{\prime} \cos (\gamma+\theta), \\
Y=-L^{\prime} \sin (\gamma+\theta) \\
L^{\prime}=L \sec \gamma \\
\theta=\pi / 2-\phi
\end{array}\right\}
$$

式(7)より $\theta$ を消去すると

$$
X^{2}+Y^{2}=(L \sec \gamma)^{2}
$$

また, 瞬間中心 $\mathrm{C}$ の固定軌跡 $\Gamma_{f}$ は, 点 $\mathrm{P}$ を静止座標 系 $\mathrm{B}_{0}-x y$ でとらえたものであり，次式によって表さ れる。

$$
\begin{gathered}
\mathrm{P}(x, y) ; x=L^{\prime} \sin \theta \sin (\gamma+\theta) \\
y=-L^{\prime} \cos \theta \sin (\gamma+\theta) \\
(x-L / 2)^{2}+(y+L \tan \gamma / 2)^{2}=(L \sec \gamma / 2)^{2}
\end{gathered}
$$

このように，中間節 C にある 2 本の直線瑇が直交し ていない場合，中間節の移動軌跡 $\Gamma_{m}$ は，図6に示す ように点 Oを中心とする半径 $L \sec \gamma$ の円となる。

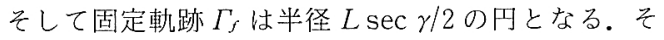
して二つの円は点 $\mathrm{P} て ゙$ 常に接し, 軌跡 $\Gamma_{m}$ の内側は, 軌跡 $\Gamma_{f}$ の外側を転がりながら運動する。

\section{3. オルダム継手の入カトルクの 理論解析}

$3 \cdot 1$ 解析モデル オルダム継手の解析モデルと しては, 図 3 のモデルを図 7 として表現する。このモ デルでは, 入・出力節として力の伝達点を一点に集中 できる形状のスライダを採用している。

3 章では出力軸に一定トルクをかける。このとき， 入力軸を回転させるのに必要な入力トルクを求める. 入力軸回転角 $\phi$ と出力回転角 $\phi$ は式 $(1) 0$ 関係にあ

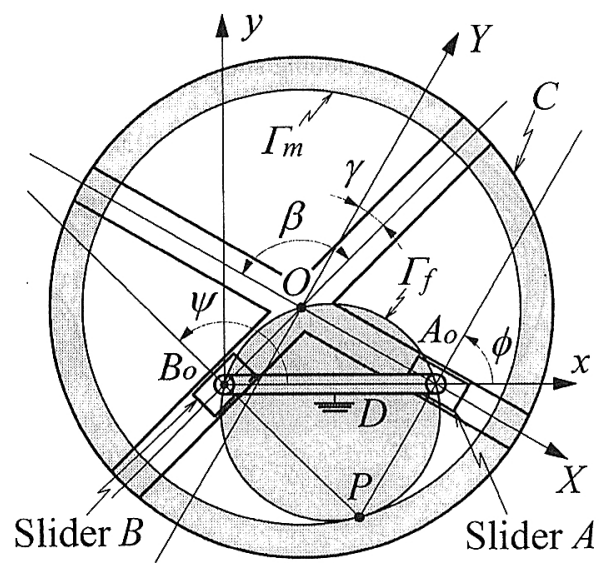

Fig. 6 Moving centrode and fixed centrode of Oldham coupling 
る.

次に，中間節の中心 $\mathrm{O}$ は，入力軸 1 回転に対しオフ セット $L$ を直径とする円 $\Gamma_{m}$ の円周上を 2 回転する.

このため中間節は, $\pi \leq \phi \leq 2 \pi$ のときは, $0 \leq \phi \leq \pi$ の ときの運動を再び繰返す。したがって, $0 \leq \phi \leq \pi$ まで の運動を解析する．次に，この解析を行う上で入力角 を次の二つの範囲に分割する。

(1) $0 \leq \phi \leq \pi / 2$

(2) $\pi / 2 \leq \phi \leq \pi$

なおっここで使用する記号は次のと扔りである。

$T_{1}:$ 入力トルク

$T_{2}$ : 出力トルク

$L:$ オセット

$M:$ 中間節の質量

$\mu:$ 摩擦係数

$F:$ 中間節に働く遠心力 $=2 M L(\mathrm{~d} \phi / \mathrm{d} t)^{2}$

$\mathrm{P}$ ：連接棒 D に対する中間節 C の䐆間中心

$r:$ 軸中心から $x$ 方向の距離

$h:$ 軸中心から $y$ 方向の距離

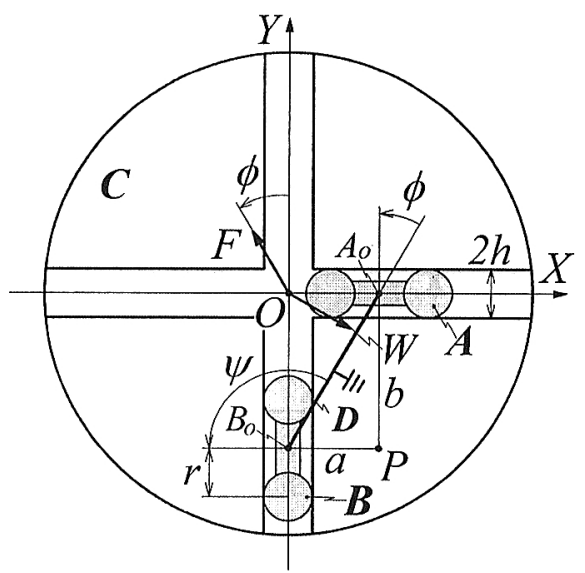

Fig. 7 Turning block double-slider crank mechanism

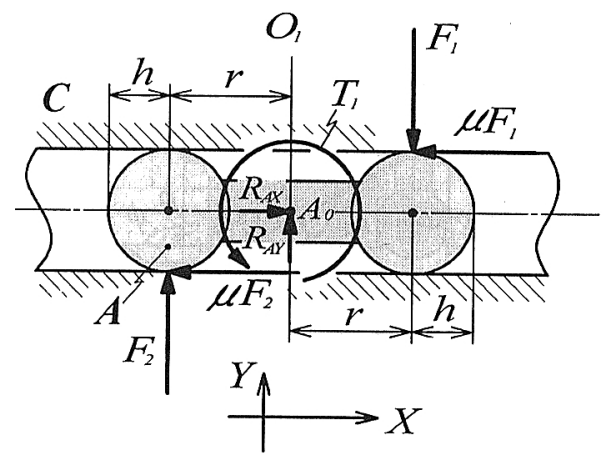

Fig. 8 Slider A
$F_{1}, F_{2}$ : スライダ A が中間節 C から受ける力 $F_{3}, F_{4}$ : スライダ B が中間節 C から受ける力 $R_{A X}, R_{A Y}: A_{0}$ 点の軸受けから受ける反力 $R_{B X}, R_{B Y}: \mathrm{B}_{0}$ 点の軸受けから受ける反力

$3 \cdot 2$ 入カトルク解析 $(0 \leq \boldsymbol{\phi}<\pi / 2) \quad$ スライダ $\mathrm{A}$ を反時計回りに回転させると, スライダ $\mathrm{A}$ は中間節 $\mathrm{C}$ を回転させる．スライダ B にかかる負荷トルク $T_{2}$ を 一定として, スライダB を回転させるのに必要なスラ イダ Aの入力トルク $T_{1}$ を求める。こ机により，スラ

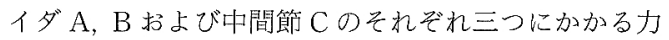
の釣合い式を求める。

（a）スライダ A に働く力の釣合い スライダ $\mathrm{A}$ が中間節 $\mathrm{C}$ から受汁る力 $F_{1}$ と $F_{2}$, 抢上び軸から受 けるトルク $T_{1}$ を図 8 に示す。スライダ $\mathrm{A}$ の基本寸法 はr,hである。

$X$ 軸方向扔よび $Y$ 軸方向に働く力の釣合いから

$$
\begin{aligned}
& -\left(\mu F_{1}+\mu F_{2}\right)+R_{A X}=0 \\
& -F_{1}+F_{2}+R_{A Y}=0
\end{aligned}
$$

$A_{0}$ 点回りのモーメントの釣合いから

$$
T_{1}-(r-\mu h) F_{1}-(r+\mu h) F_{2}=0
$$

(b) 中間節 C に働く力の釣合い 中間節 Cが スライダ $\mathrm{A}, \mathrm{B}$ から受ける力 $F_{1}, F_{2}, F_{3}, F_{4}$ および中 間節 $C$ の重量 $W$ を図 9 に示す。な抢重量 $W$ は, $W$ $=M g$ であり，中間節の $\overline{\mathrm{A}_{0} \overline{\mathrm{B}}_{0}}$ に垂直方向に働く. $X$ 軸方向抒上び $Y$ 軸方向侄く力の釣合いから

$$
\left.\begin{array}{r}
\mu\left(F_{1}+F_{2}\right)+F_{3}-F_{4} \\
+W \cos \phi-F \sin \phi=0
\end{array}\right\}
$$

$\mathrm{P}$ 点回りのモーメントの釣合いから

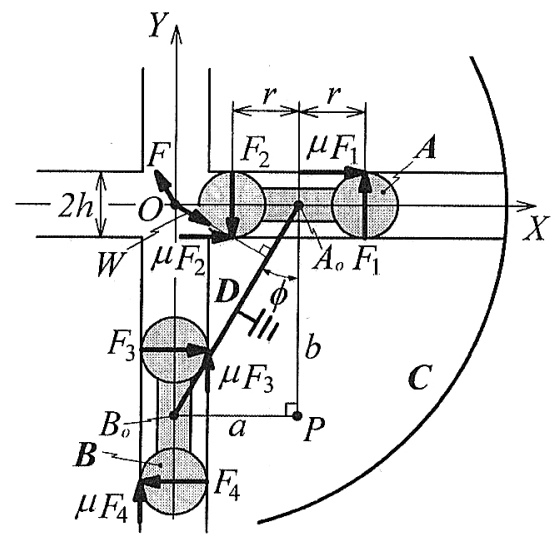

Fig. 9 Intermediate element $C$ 


$$
\left.\begin{array}{l}
\{r-\mu(b+h)\} F_{1}+\{r-\mu(b-h)\} F_{2} \\
\left.\quad-\{r+\mu(a-h)\} F_{3}-\{r+\mu(a+h)\} F_{4}\right\} \\
\quad+(a \sin \phi-b \cos ) W=0
\end{array}\right\}
$$

ここで

$$
a=L \sin \phi, b=L \cos \phi
$$

(c) スライダ Bに働く力の釣合い 図 10 にス ライダ $\mathrm{B}$ が中間節 $\mathrm{C}$ から受ける力 $F_{3}, F_{4}, \mu F_{3}, \mu F_{4}$ お よび軸から受けるトルク $T_{2}$ を示す。スライダ $\mathrm{B} の$ 基 本寸法は $r, h$ である。

$X$ 軸方向および $Y$ 軸方向に働く力の釣合いから

$$
\begin{aligned}
& -F_{3}+F_{4}+R_{B X}=0 \\
& -\left(\mu F_{3}+\mu F_{4}\right)+R_{B X}=0
\end{aligned}
$$

$\mathrm{B}_{0}$ 点回りのモーメントの釣合いから

$$
T_{2}-(r-\mu h) F_{3}-(r+\mu h) F_{4}=0
$$

(d) 入力トルク $T_{1}$ 入力角であるスライダ $\mathrm{A}$

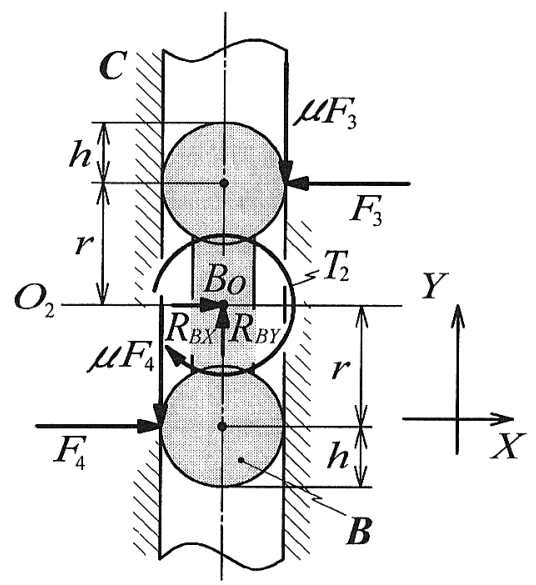

Fig. 10 Slider B

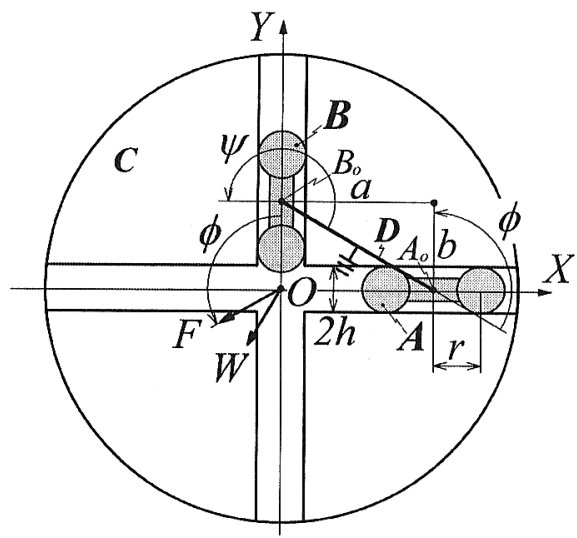

Fig. 11 Turning block double-slider crank mechanism
の回転角を $\phi$ として，T $T_{1}$ 次式として求める.

$$
T_{1}=f\left(r, h, L, \mu, M, T_{2}, \phi\right)
$$

式 (25)〜 (27)，(31) は $F_{1}, F_{2}, F_{3}, F_{4}$ を末知数とす る 4 元の連立方程式となる.この 4 元の連立方程式を 解き $F_{1}, F_{2}$ を式 (24) に代入すると入力トルク $T_{1}$ は次 式となる.

$$
\left.\begin{array}{rl}
T_{1} & =\left\{r^{2} L \cos (2 \phi) W-\mu^{2} r h L \cos (2 \phi) F\right. \\
& \left.+\left(r^{2}+r \mu L \sin \phi\right) T_{2}\right\} /\left(r^{2}-r \mu L \cos \phi\right)
\end{array}\right\}
$$

なお， $F$ は遠心力であり $F=2 M L(\mathrm{~d} \phi / \mathrm{d} t)^{2}$ で表さ れる。

$3 \cdot 3$ 入力トルク解析 $(\pi / 2 \leq \boldsymbol{\phi}<\boldsymbol{\pi})$ 図 11 に入 力軸回転角が $\pi / 2 \leq \phi<\pi の$ 場合の回り両スライダ機 構を示す.

(a) スライダ $\mathrm{A}$ に働く力の釣合い スライダ $\mathrm{A}$ が中間節 C から受ける力 $F_{1}, F_{2}$ および軸から受け るトルク $T_{1}$ を図 12 に示寸. スライダ $\mathrm{A} の$ 基本寸法 は $r, h$ である。

$X$ 軸方向および $Y$ 軸方向に働く力の釣合いから

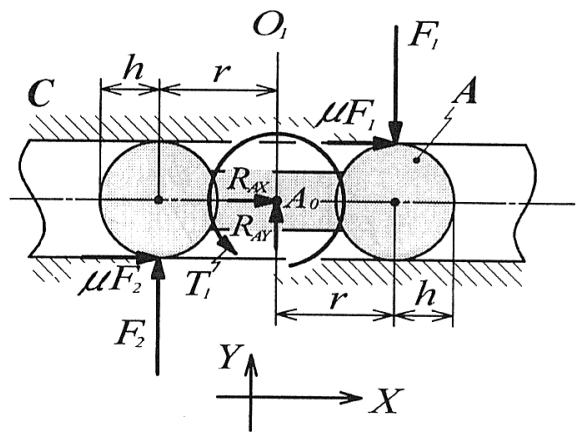

Fig. 12 Slider A

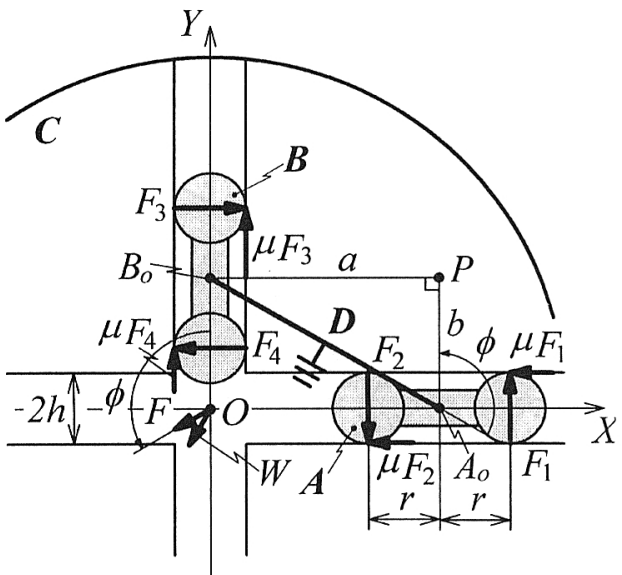

Fig. 13 Intermediate element C 


$$
\begin{aligned}
& \left(\mu F_{1}+\mu F_{.2}\right)+R_{A X}=0 \\
& -F_{1}+F_{2}+R_{A Y}=0
\end{aligned}
$$

$\mathrm{A}_{0}$ 点回りのモーメントの釣合いから

$$
T_{1}-(r+\mu h) F_{1}-(r-\mu h) F_{2}=0
$$

(b) 中間節 Cに働く力の釣合い 中間節 Cが スライダ $\mathrm{A}, \mathrm{B}$ から受ける力 $F_{1}, F_{2}, F_{3}, F_{4}$ および中 間節の重量 $W$ を図 13 に示す。な括中間節 Cの重量 $W$ は $W=M g$ である.

$X$ 軸方向抢よび $Y$ 軸方向に働く力の釣合いから

$$
\left.\begin{array}{r}
-\mu\left(F_{1}+F_{2}\right)+F_{3}-F_{4} \\
+W \cos \phi-F \sin \phi=0
\end{array}\right\}
$$

$\mathrm{P}$ 点回りのモーメントの鈎合いから

$$
\begin{aligned}
& \{r-\mu(b-h)\} F_{1}+\{r-\mu(b+h)\} F_{2} \\
& \left.\quad-\{r+\mu(a-h)\} F_{3}-\{r+\mu(a+h)\} F_{4}\right\} \\
& \quad+(a \sin \phi+b \cos ) W=0
\end{aligned}
$$

$$
\text { ここで }
$$

$a=L \sin \phi, b=-L \cos \phi$

(c) スライダ B に働く力の釣合い 図 14 にス ライダB が中間節 C から受ける力 $F_{3}, F_{4}, \mu F_{3}, \mu F_{4}$ 打 よび軸から受けるトルク $T_{2}$ を示す。スライダ $\mathrm{B} の$ 基 本寸法は $r, h$ である。

$X_{1}$ 軸方向および $Y_{1}$ 軸方向に働く力の釣合いから

$$
\begin{aligned}
& -F_{3}+F_{4}+R_{B X}=0 \cdots \\
& -\left(\mu F_{3}+\mu F_{4}\right)+R_{B X}=0
\end{aligned}
$$

$\mathrm{B}_{0}$ 点回りのモーメントの釣合いから

$$
T_{2}-(r-\mu h) F_{3}-(r+\mu h) F_{4}=0
$$

(d) 入力トルク $T_{1}$ 入力角であるスライダ $\mathrm{A}$ の回転角を $\phi$ として，T次式として求める。

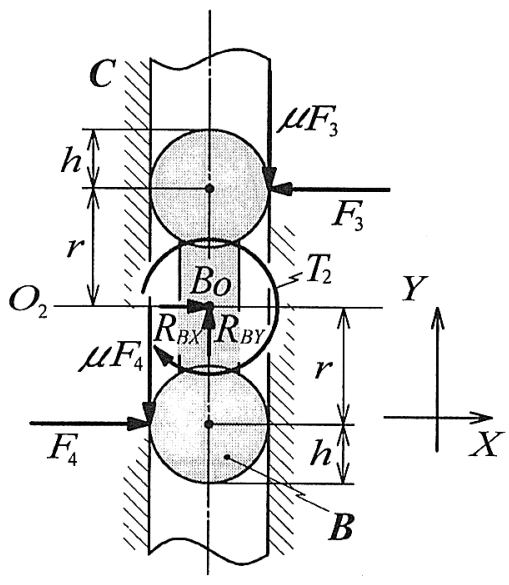

Fig. 14 Slider B

$$
T_{1}=f\left(r, h, L, \mu, M, T_{2}, \phi\right)
$$

式(13) (15)，(19) は $F_{1}, F_{2}, F_{3}, F_{4}$ を末知数とす る 4 元の連立方程式となる。この 4 元の連立方程式を 解き $F_{1}, F_{2}$ を式(12)に代入すると入力トルク $T_{1}$ は次 式となる.

$$
\left.\begin{array}{rl}
T_{1} & =\left\{r^{2} L \cos (2 \phi) W-\mu^{2} r h L \cos (2 \phi) F\right. \\
& \left.+\left(r^{2}+r \mu L \sin \phi\right) T_{2}\right\} /\left(r^{2}+r \mu L \cos \phi\right)
\end{array}\right\}
$$

\section{4. 実 験 検 証}

$4 \cdot 1$ 実験装置および実験方法本実験で用いた 実験装置の概略を図 15 に示す。この装置はモータか らの回転運動を入力軸, 中間節, 出力軸の順に伝達す る.また, 入力軸にトルク計を設置し, 入力軸にかか るトルクを測定する。なお，出力軸に一定の負荷トル クを与光, オフット $L$ は出力軸側の軸受台を平行 移動させることによって与えている。一定負荷トルク は出力軸にプーリをつけ，プーリに吊り下げられた重 りによって与えられている。

図 16 に本実験に用いたオルダム継手を示す。また， 実験に使用したオルダム継手の諸元と実験条件を下記 に示す。なお，摩擦係数は静摩擦係数の実測值を用い ている.

$T_{2}=0,0.075 \mathrm{~N} \cdot \mathrm{m}, M=0.292 \mathrm{~kg}$

$\mu=0.2, L=5 \mathrm{~mm}$

$r=20 \mathrm{~mm}, h=4 \mathrm{~mm}, n=120 \mathrm{~min}^{-1}$

$4 \cdot 2$ 入カトルクの理論值と実験值の比較 図 17 に出力トルク $T_{2}=0 \mathrm{~N} \cdot \mathrm{m}$, 図 18 に出力トルク $T_{2}=$ $0.075 \mathrm{~N} \cdot \mathrm{m}$ の場合の入力トルクの理論值と実験值を 示す. 理論值と実験值を比較すると, 雨者はよく一致 している.この結果は, 解析モデルによるトルク解析 の妥当性を証明している.

$4 \cdot 3$ 入カトルク変動の摩擦係数の影響 $4 \cdot 2$ 節 の解析に扔いては, 本来, 動摩擦係数を用いるべきで ある.しかし，動摩擦係数の測定は非常に困難なため

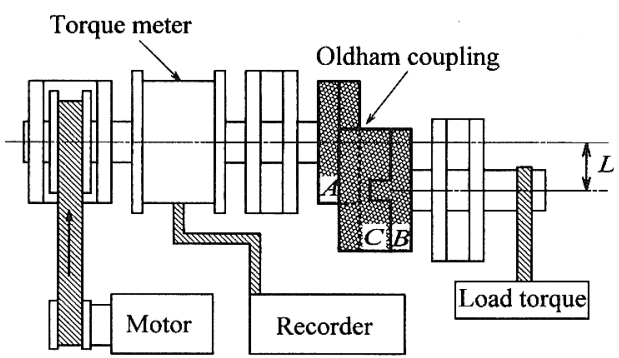

Fig. 15 Experimental apparatus 
静摩擦係数の実測值を用いている。な扔, 摩擦係数の 変動トルクへの影響を調べるために摩擦係数 $\mu$ を，

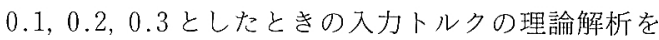
行った。その結果を図 19 に示す。な扔，出力トルク $T_{2}$ は $0 \mathrm{~N} ・ \mathrm{~m}$ である。図 19 に示すように, 摩擦係数 ルは変動トルクの值にほとんど影響しない.

\section{5. 結言}

（1）オルダム継手の中間節の運動を解析した.中 間節の瞬間中心の固定軌跡を $\Gamma_{f}$ とし，その移動軌跡 を $\Gamma_{m}$ とする. 入力節と出力節の軸間距離を $L$ とする と, 軌跡 $\Gamma_{f}$ は半径 $(L / 2)$ の円となり, 軌跡 $\Gamma_{m}$ は半径 $L の$ となる.そして, 入力節, 中間節, 出力節を回 転させるとき，軌跡 $\Gamma_{m}$ の内側は，軌跡 $\Gamma_{f}$ の外側を転 がる.中間節の運動は，中間節に固定された軌跡 $\Gamma_{m}$ の内側が固定節に固定された軌跡 $\Gamma_{f}$ の外側を転がり ながら運動寸る，いわゆるフラフープのような運動で

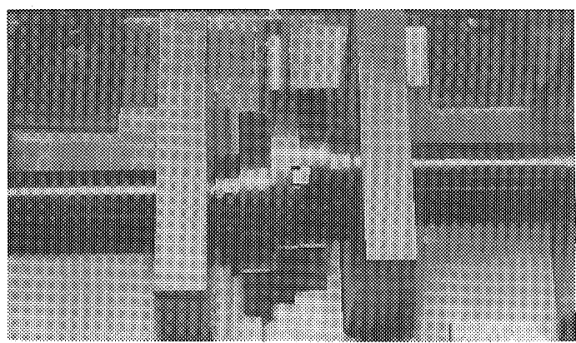

Fig: 16 Oldham coupling

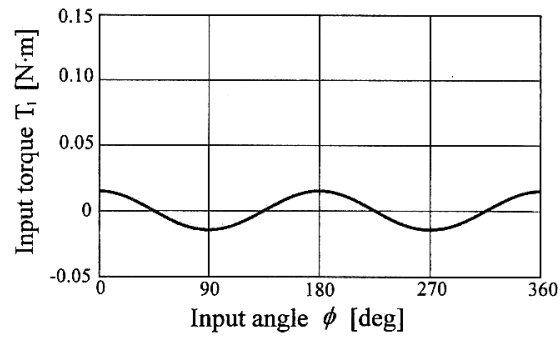

(a) Theoretical curve of input torque

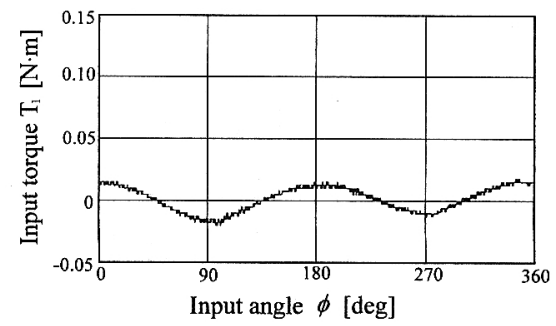

(b) Experimental curve of input torque

Fig. 17 Output torque $T_{2}=0 \mathrm{~N} \cdot \mathrm{m}$
ある。

（2）中間節が直交しない場合でも，オルダム継手 は, 入出力軸間に等速運動を伝える。ここに角 $\gamma$ は, 2 本の湛のなす角 $\left(90^{\circ}+\gamma\right)$ にって定義された角であ る。この場合, 中間節の固定軌跡 $\Gamma_{f}$ は半径 $(L \mathrm{sec}$ $\gamma / 2)$ のとなり，その移動軌跡 $\Gamma_{m}$ は半径 $L \sec \gamma$ の 円となる.中間節の運動は先ほどの場合と同様に，中 間節に固定された軌跡 $\Gamma_{m}$ の内側が固定節に固定され た軌跡 $\Gamma_{f}$ の外側を転がりながら運動する，いわりる フラフープのような運動である。

（3）以上の運動解析に基づいて, 入力トルクを理

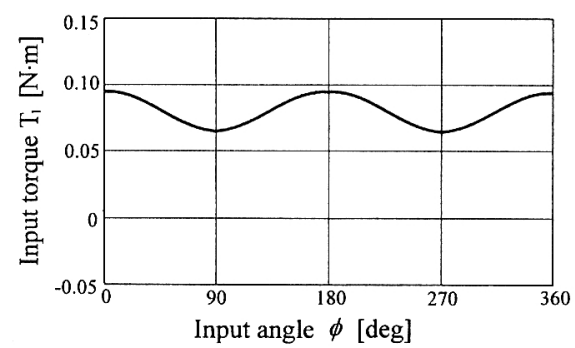

(a) Theoretical curve of input torque

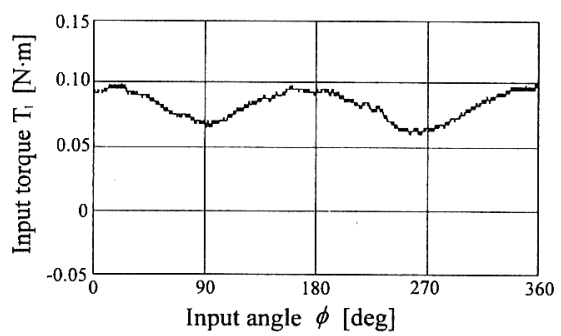

(b) Experimental curve of input torque

Fig. 18 Output torque $T_{2}=0.075 \mathrm{~N} \cdot \mathrm{m}$

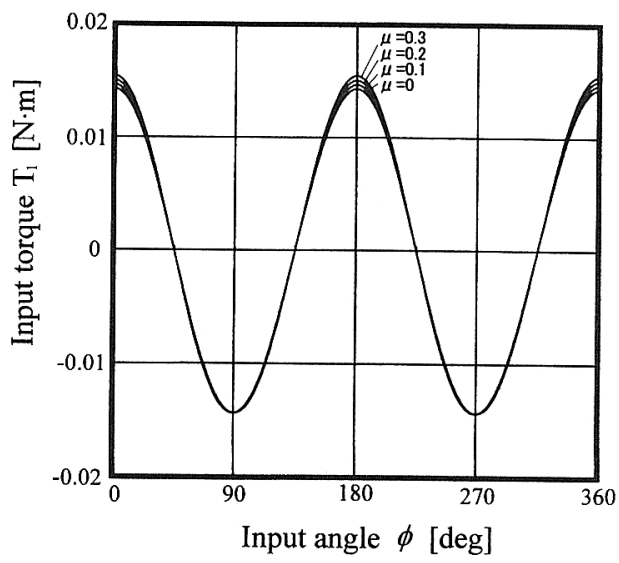

Fig. 19 Theoretical curve of input torque (output torque $T_{2}=0 \mathrm{~N} \cdot \mathrm{m}$ ) 
論的に求めた.さらに実際にオルダム継手を設計・製 作した。そして夷験によってその入力トルクを測定し た. 入力トルクの理論値は, 実験值とよく一致した. この結果は, 解析モデルによるトルク解析の妥当性を 証明している.

（4）以上本研究は, オルダム継手の運動と力学的 挙動を解明しており,オルダム継手の設計・製作に寄 与することができる。また，だ円切削装置の開発のた めの基礎デー夕を提供している.
終わりに, 本研究には, 本学の多くの大学院生, お よび卒業研究生が参加してきた.これら各位に対して 心から感謝する。

\section{文献}

(1) Peuleaux, F., The Kinematics of Machinery, (1963), 316.

（2）稲田重男・隻田雅男・林則行 - 本郷薫, 機構学, (1961), 78 , 朝倉書店. 